\section{若年者の突然死の予防について}

若年者然然死の大部分は，一部の頭蓋内出血な ぞを除くと大部分が心臟性である。その予防のた

1）日本体育・学校健康センター：学校の管理下の死 亡・障害(平成 5 年版)。 日本体育・学校健康セン 夕一編

2）大国真彦：小児における突然死の疫学. カレント
めには，危険な病型を見逃さない心蔵検診の実施 と，発見された危険な病型例に対する十分な管理 指導が重要で，特に循環器専門医の適切な関与が 大切であると考えられた。

献

テラピー $1994 ; \mathbf{1 2}: 20-23$

3）大国真彦 他：小児心疾患々突然死。小児科 $1973 ; \mathbf{1 4}: 1103$

\title{
Fontan 型手術
}

1971年 Fontan らは, 二尖弁閉鎖に対して体静 脈血を右室を介さずに右房から直接肺動脈に導 く手術を行い，いわゆる機能的単心室を伴う複 杂隹先天性心疾患に対する機能的修復の先鞭をつ けた。術式は右心耳を直接肺動脈に吻合する方 法などの他, 低形成右室の一部を使用する Björk 法などの変法があり，また近年は心房内グラフ トによる心房内分離に，上大静脈一肺動脈の端側 吻合を行j TCPC 法 (total cavo pulmonary connection)が広く行われ，これらをFontan 型 手術と総称している. 当初 Choussat らはFontan 型手術の適応基準として，(1)手術時年齢 4 藏以 上，(2)洞調律，(3)正常体静脈還流，(4)正常右房 容積，(5)平均肺動脈圧 $16 \mathrm{mmHg}$ 以下，(6)肺血管 抵抗值 4 単位以下，(7)肺動脈大動脈径比0.75以
上，(8)正常左室機能，(9)僧帽弁閉鎖不全なし， (10)姑息的手術による障害なし，の俗に《Fontan の十戒》と呼ばれる条件を示した。しかし現在 では，これらのすべてが必須条件とはされず， 肺動脈の発達が十分で，肺動脈圧，肺血管抵抗 が適切で，体循環系心室となる心室機能が良好 であれば，十分手術可能であり，単心室群を含 め多くの複雑心奇形にその適応が拡大され，手 術成績も向上してきている。しかし肺循環系心 室を省略した，きわめて特異な循環動態となる 手術方法であるため，体静脈系の圧上昇，うっ 血による肝機能障害，抢よび低心拍出状態，運 動能低下などの問題点が術後にも残され，その 長期遠隔子後に関しては不明な部分がある。

(高橋長裕) 